\title{
Obituary for Donald S. Coffey: Pioneer in the field of prostate cancer research. Born in Bristol on October 10, 1932, he died in Baltimore on November 9th, 2017, at the Age of 85
}

Donald S. Coffey, Ph.D., "Don", was born in Bristol, a twin city on the border of Virginia and Tennessee, on October 10, 1932. As a young man, he grew up working at his father's automobile service station. He then attended King College in Bristol, Tennessee. In 1953, after leaving King College, he entered the University of East Tennessee. In 1955, he was hired by the North American Rayon Company where he served as a chemist and engineer. During these early years, he would use meditation to reflect upon life, creativity, and the universe. During one of these sessions, his mind inexplicably turned to cancer. He decided, rather unexpectedly, that he would change his life and career to study cancer. Speaking about this with a colleague and mentor at North American Rayon, Dr. Lee R. Herdon, he learned of Johns Hopkins as a top institute to pursue this "hunch". Dr. Coffey, his wife Eula, and their young daughter packed their bags and moved to Baltimore.

Don worked his way into Hopkins as a volunteer, washing glassware at night and spending free time with scientists, while working days as an engineer at the Westinghouse Electronic Corporation in Baltimore on inflatable antennas. He often recalled the advice he received from James W. Currie, his supervisor at Westinghouse, whom he referred to as "Big Jim". When Big Jim was presented with solutions to problems the team encountered, he would often say, "That's too complicated, Coffey. We have to find a simple solution". Don followed this advice throughout his career and imparted it to the many individuals he trained and advised. The article in issue N14 entitled Symmetry and Symmetry Breaking in Cancer: A Foundational Approach to the Cancer Problem embraces this sound admonition and presents a new view on simplifying the complexity of cancer.

Don attended evening classes at McCoy College, the Hopkins night school, and soon obtained a position as a technician at the Brady Research Laboratory where he worked nights with Charles Tesar, while keeping his primary job at Westinghouse. With the sponsorship of Dr. William Scott, director of the Brady Urologic Institute, he became acting director of the Brady Urological Research Laboratory from 1959 to 1960, left his position at Westinghouse, and entered the graduate program in the medical school's department of physiological chemistry and received his Ph.D. in 1964.

During the late 1960s, Don became involved in research with the Brady Institute during Dr. Guy Williams-
Ashman's tenure as director of the Brady Laboratory for Reproductive Biology. Upon Dr. Williams-Ashman's return to Chicago in 1969 , He became director of the laboratory and his versatility attracted notice in other Hopkins departments. He chaired the Department of Pharmacology without ever taking a course in pharmacology. With no medical degree, he helped found the Cancer Center in 1973 with its first director, Albert Owens, and then ran it briefly in 1987. Don became one of Johns Hopkins' first triple professors, and went on to serve as faculty in the departments of Urology, Oncology, Pharmacology and Molecular Sciences, and Pathology. From 1974-2004, he served as Director of Research for the Brady Urologic Institute. Among his many scientific accomplishments was his pioneering work in defining the nuclear matrix and studying nuclear structure and chromatin organization. In the urologic community, he is renowned for his mentorship and training of many outstanding leaders in the field of urology and cancer research. This family extends beyond direct trainees. Don interacted and mentored any ambitious student, clinician and/or scientist who knocked on his door or stopped him in the hallways of Johns Hopkins or at a national meeting. Recently, the James Buchanan Brady Urologic Institute produced a full length film about Dr. Coffey and his legacy, which can be viewed at their website (http:// urology.jhu.edu/videos/history.php).

During his career Don was a member of the president's committee on governance at the Hopkins School of Medicine, a member and first faculty-elected vice-chairman of the medical school council, the advisory board, the committee on educational policy and curriculum, the professional promotions committee, the medical scientist training program and the committee on cultural and social affairs. From the U.S. Public Health Service, he received the Research Career Development Award from 1966 to 1972 and was in the experimental therapeutics study section from 1971 to 1975 . He was a member of the National Prostatic Cancer Task Force, Working Cadre, and the President's Cancer Advisory Board. He has served on the editorial boards of The Journal of Urology ${ }^{\circledR}$, Advances in Sex Hormone Research, International Union Against Cancer, Prostate and the World Journal of Urology. In addition, he was the 1992 recipient of the American Urological Association's Eugene Fuller Triennial Prostate Award and the 2001 AUA Certificate of Achievement Award, which recognized his 
lifetime of career achievements in urology. In 2015 he received the AACR Margaret Foti Award for Leadership and Extraordinary Achievements in Cancer Research. Many of Don's protégés are leaders in prostate cancer research today.

Dr. Donald S. Coffey will be missed by his colleagues, friends, and family around the world. He was very happy to have learned shortly before his death that the article in issue N14 on cancer symmetry breaking was accepted for publication in Oncotarget. 